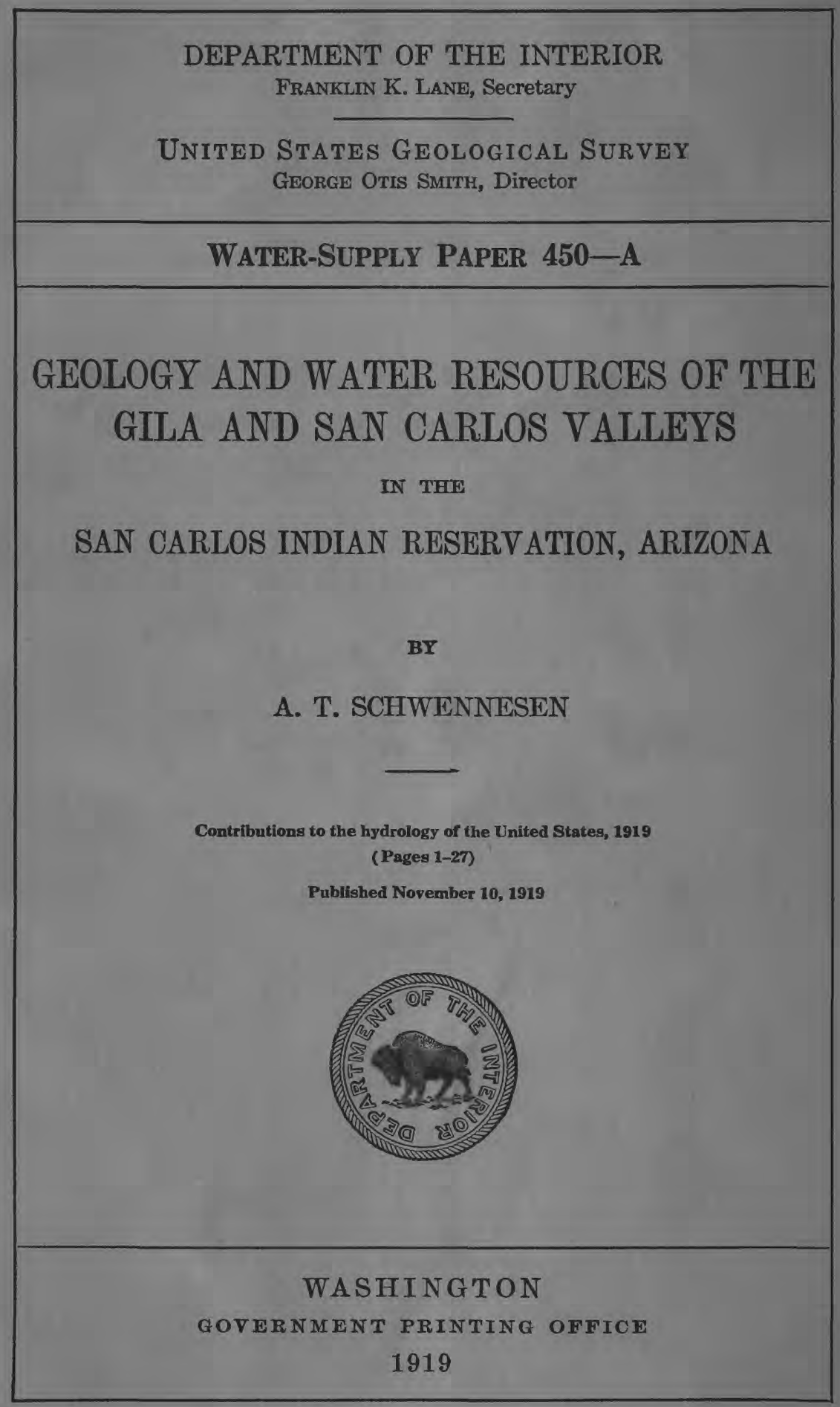



DEPARTMENT OF THE INTERIOR

FrankLin K. Lane, Secretary

United States Geological Survey

George OTIS SMITH, Director

Water-Supply Paper 450-A

\section{GEOLOGY AND WATER RESOURCES OF THE GILA AND SAN CARLOS VALLEYS}

IN THE

SAN CARLOS INDIAN RESERVATION, ARIZONA

BY

A. T. SCHWENNESEN

Contribations to the hydrology of the United States, 1919

(Pages 1-27)

Published November 10, 1919

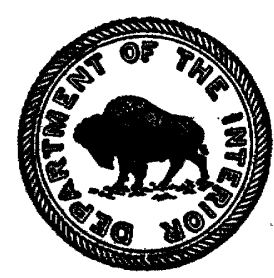

WASHINGTON

GOVERNMENT PRINTING OPFTOA

1919 


\section{CONTENTS.}

Introduction

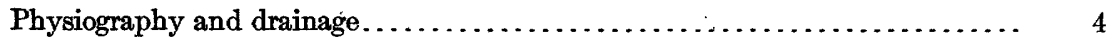

General features.......................................... 4

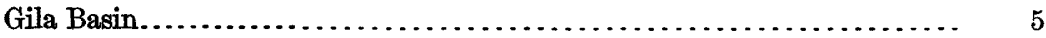

San Carlos Basin............................................ 5

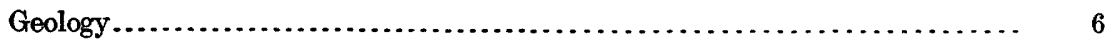

Igneous rocks............................................... 6

Sedimentary rocks........................................... 6

Pre-Quaternary rocks...................................... 6

Quaternary deposits...................................... 7

General character.................................. 7

Gila conglomerate................................... 7

Lake beds............................................ 8

Alluvium........................................... 10

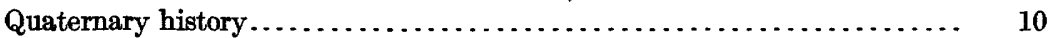

Classification of lands.............................................. 10

Surface water supply......................................... 11

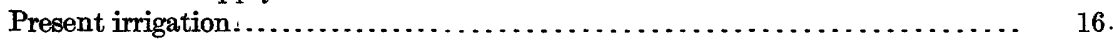

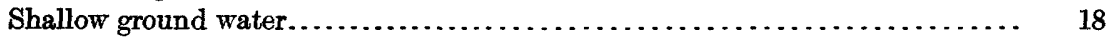

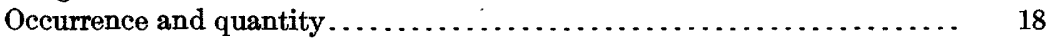

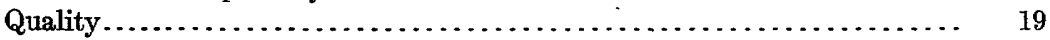

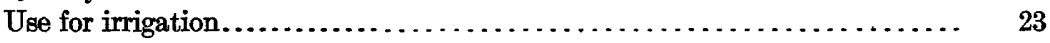

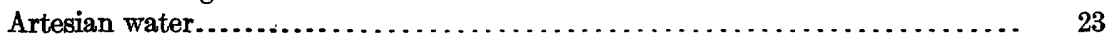

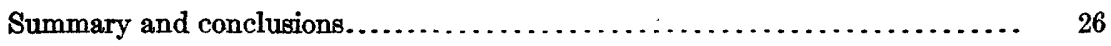

\section{IILUSTRATIONS.}

Plate I. Map of Arizona showing areas covered by reports of the United States Geological Survey relating te ground water.

II. Geologic map of Gila Basin and parts of San Carlos Basin, San Carlos Indian Reservation, Ariz.............................

III. Map of a part of Gila Valley in San .Carlos Indian Reservation, Ariz., above San Carlos réservoir site, showing classification of lands and location of wells and springs, with notes on topography and native vegetation.

IV. Map of a part of San Carlos Valley in San Carlos Indian Reservation, Ariz., above San Carlos reservoir site, showing classification of lands and location of wells, with notes on soil, topography, and

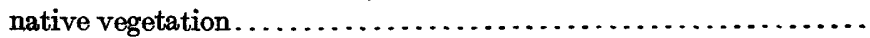

Frgure 1. Map of San Carlos Indian Reservation, Ariz., and adjacent regions, showing physiographic provinces.......................

2. Generalized view and cross section of Gila Basin, San Carlos Indian Reservation, Ariz., showing physiography and geology.......... 


\section{CONTRIBUTIONS TO THE HYDROLOGT OF THE UNITED STATES, 1919.}

Nathan C. Grover, Chief Hydraulic Engineer.

\section{GEOLOGY AND WATER RESOURCES OF THE GILA AND SAN CARLOS VALLEYS IN THE SAN CARLOS INDIAN RESERVA- TION, ARIZONA.}

By A. T. Schwennesen.

\section{INTRODUCTION.}

In recent years the Indian farmers in the valleys of Gila and San Carlos rivers, in the San Carlos Indian Reservation (PI. I and fig. 1), have been seriously handicapped by an inadequate supply of water for irrigating their crops. A shortage of water at times when it is most needed has tended to discourage those Indians who are making an earnest effort to farm and has done much toward neutralizing the efforts of the reservation officials to interest others in agriculture. The water shortage has been due to a lack of water in the streams at certain times of the year and to the difficulties of keeping diversion dams and ditches in operation on account of washouts caused by sudden floods in the rivers and by torrents in the tributary arroyos during heavy rains. In the river valleys many tracts of good land now lying idle could be made productive if sufficient water were obtainable. An extension of the present system to include these lands, however, would be likely to fail, from the same causes that contribute to the inadequacy of the present system.

Several officials of the United States Office of Indians Affairs, who are familiar with conditions in the reservation, have suggested the use of ground water for irrigation, and in response to these suggestions the Indian Office requested the United States Geological Survey to make an investigation of the ground-water conditions. The purpose of this investigation, as expressed in the letter of authorization, was "to determine the feasibility of drilling for an irrigation water supply, the examination to be restricted to land not included within the proposed San Carlos reservoir." 
The field work covered a period of three months and was completed in December, 1914. Soon after its completion a report was made to the Indian Office containing (1) a brief description of the geologic conditions which influence the occurrence of ground water in this

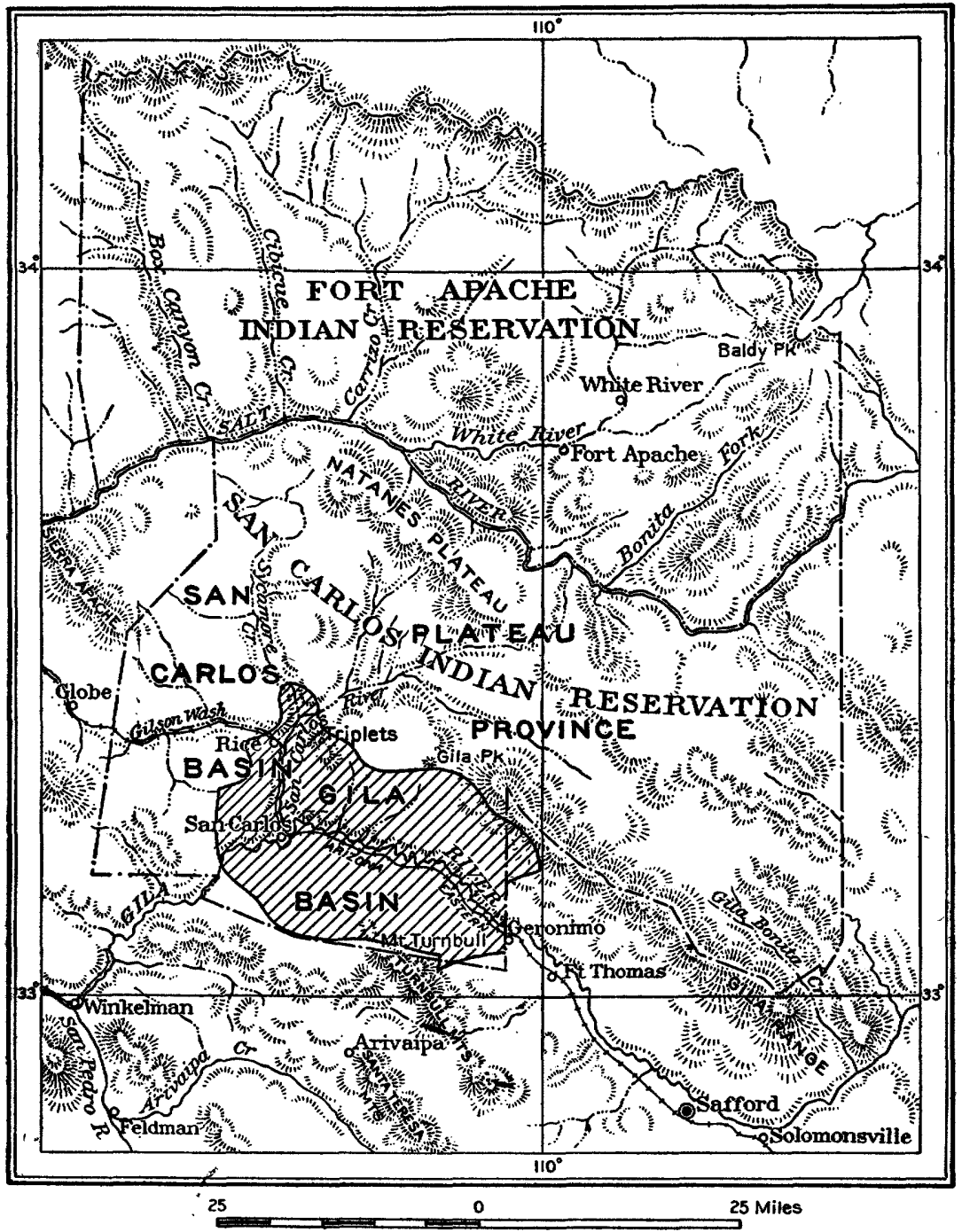

Frgura 1.-Map of Sin Carlos Indian Reservation, Ariz., and adjacent regions, showing physiographic provinces.

region, (2) a discussion of the available pumping supplies in the Gila and San Carlos valleys, (3) a discussion of the artesian possibilities, and (4) a summary of conclusions, with certain definite recommendations as to the mode of procedure to develop a sufficient 


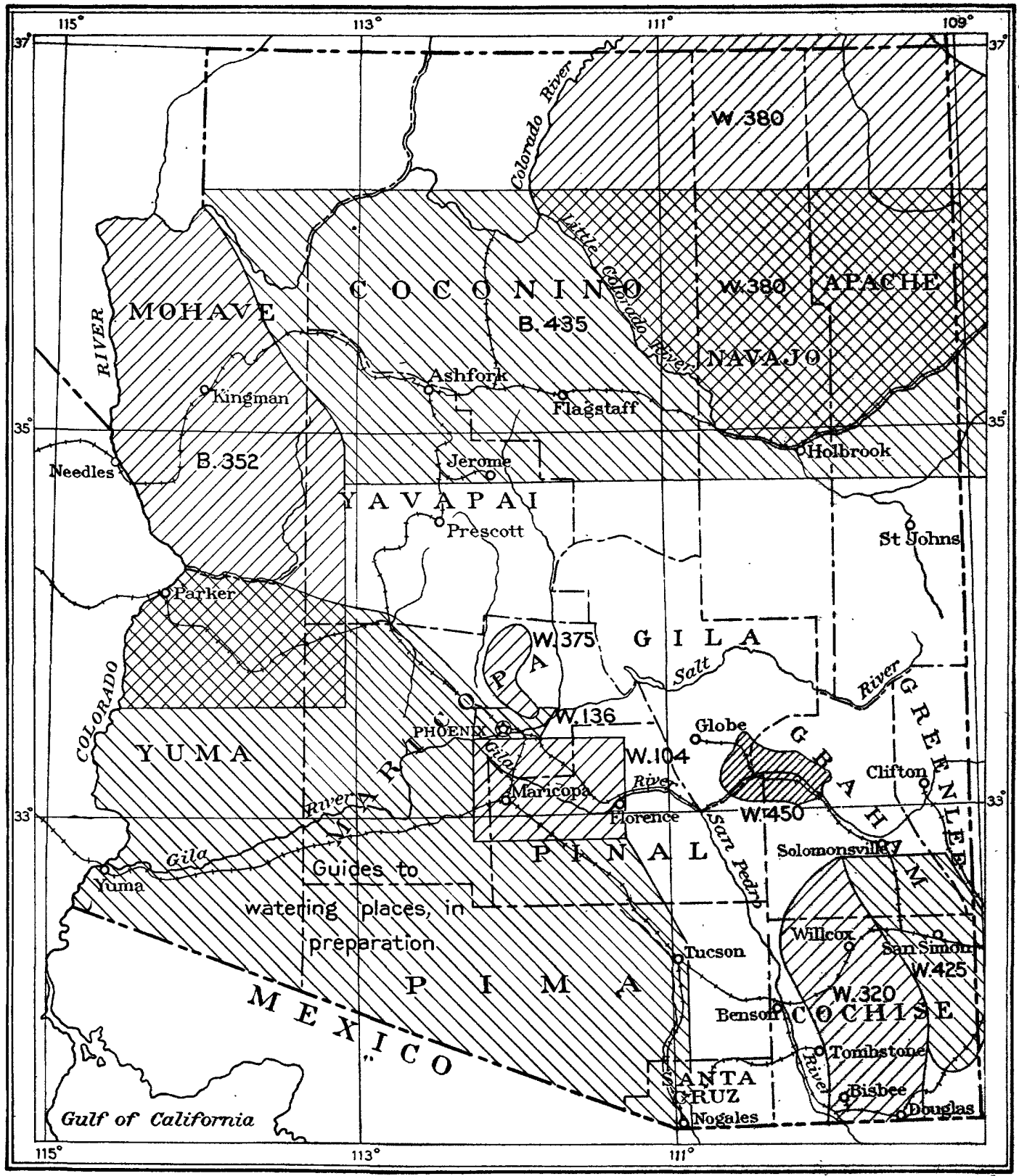

50

50

100 Miles

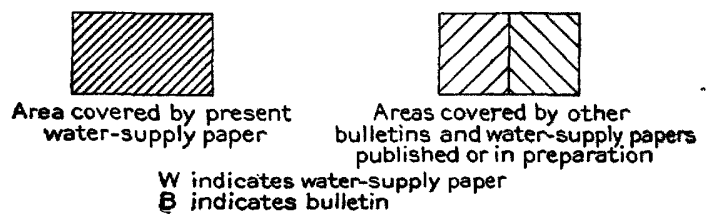

MAP OF ARIZONA SHOWING AREAS COVERED BY REPORTS OF THE UNITED STATES GEOLOGICAL SURVEY RELATING TO GROUND WATER. 
ground-water supply and to increase the irrigated acreage in the reservation. The work was done under the direction of O. E. Meinzer, geologist in charge of the Survey's investigations relating to ground water.

To determine the available supplies for pumping from wells in the river valleys a study was made of the valley sediments with reference to their water-bearing capacity. To determine the quality of this supply for irrigation water samples were collected from representative wells and sent to the University of Arizona for analysis.

The artesian problem required the mapping of the geologic formations in the Gila and San Carlos basins and a study of their structure. The results are shown in Plate II and figure 2. Before recommending the development of either a pumped or artesian water supply it was

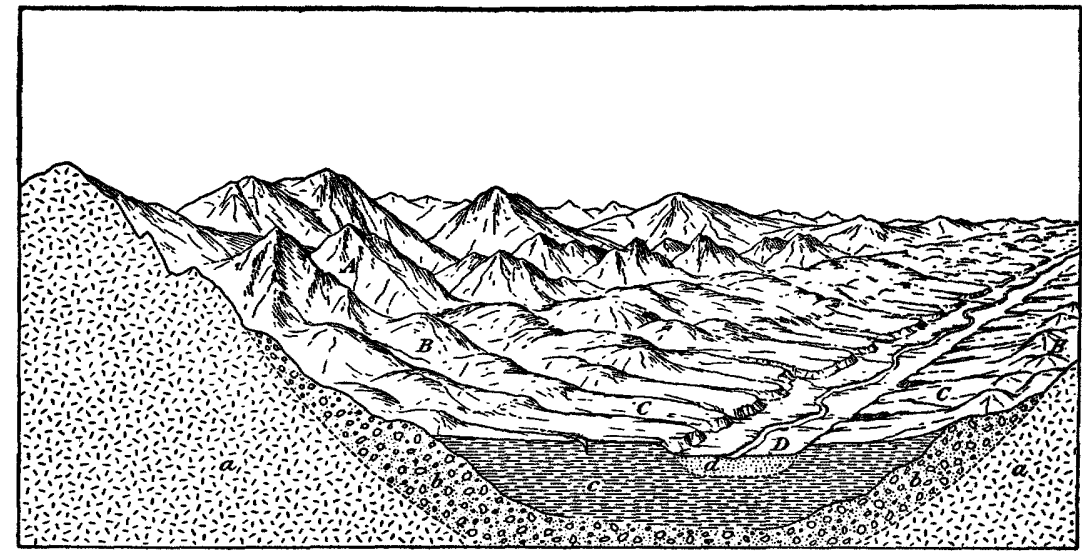

FTaURe 2.-Generalized view and cross section of Gila Basin, San Carlos Indian Reservation, Ariz., showing physiography and geology. $A$, Mountains; $B$, hilly belts, produced by erosion of older alluvial material (b); $C$, dissected ancient lake bottom; $D$, valley of Gila River, produced by erosion of lake beds $(c)$ and later deposition of alluvium $(d) ; a$, pre-Quaternary igneous and sedimentary rocks; $b$, Gila conglomerate; $c$, lake beds; $d$, Recent alluvium.

important to know whether the amount of arable land in the San Carlos and Gila valleys above the proposed reservoir site was sufficient to warrant the drilling of deep wells or the construction of pumping plants. For this purpose a plane-table map on a scale of 2,000 feet to the inch was made of the portions of the San Carlos and Gila valleys above the proposed site (Pls. III and.IV).

It was originally planned to include the results of this investigation in a more comprehensive paper on parts of southeastern Arizona. On account of the writer's resignation from the Geological Survey and the changes produced by the war the publication of such a paper has been indefinitely postponed, and it appears desirable to publish the present brief report, not only to make the local data more accessible but also because of the bearing of these data on the geologic history and ancient lakes or other bodies of standing water that have 
been observed in the fill of other parts of Gila Valley, in the fill of San Simon and San Pedro valleys, and, with less certainty, in the fill of Sulphur Spring and San Bernardino valleys. ${ }^{1}$ These deposits in Gila, San Pedro, and San Simon valleys are no doubt related to one another and have an important bearing on the late geologic history and also on the water supply of the region.

Acknowledgments are due to the superintendent of the reservation, Mr. A. L. Lawshe, and to others for assistance in conducting the field work and for many courtesies; to Mr. C. H. Southworth, engineer of the Indian Office, for furnishing water analyses and for extending the hospitality of his camp; and to the University of Arizona and Mr. A. E. Vinson, of the university staff, who made analyses of the well waters that were collected.

\section{PHYSIOGRAPHY AND DRAINAGE.}

\section{GENERAL FEATURES.}

The San Carlos Indian Reservation can be divided into two partsa plateau area, characterized by mountains and lava plateaus, and a basin area, characterized by broad intermontane basins or valleys underlain by river and lake deposits.

The plateau area covers most of the northern and eastern parts of the reservation, including the Ash Flat and Natanes plateaus. Its southern margin is formed by the Gila Range, and its western boundary by a line drawn approximately northward from the Triplets to the Salt River divide. (See fig. 1.)

The basin area includes the Gila Basin, an intermontane trough traversed by Gila River, which flows westward through the southern part of the reservation, and the San Carlos Basin, a similar trough traversed by San Carlos River, which flows southward through the western part of the reservation to San Carlos, where it discharges into the Gila. The basin area is bounded on the south by the Turnbull Range, on the west by the eastern ridges of the Mescal, Pinal, and Apache mountains, and on the north in part by the Gila Range. (See fig. 1.)

With the exception of a narrow strip of country south of Salt River, all of the reservation drains through a gorge which the Gila has cut in the Mescal Range and which is known as the box canyon. The southern part of the reservation, between the Gila and Turnbull ranges, drains directly into Gila River, which crosses the east boundary 2 miles west of Geronimo and flows west-northwestward for 25 miles to its junction with the San Carlos and thence southwestward for 10 miles to the southern boundary of the reservation.

1 Blake, W. P., Lake Quiburis, an ancient Pliocene lake in Arizona: Arizona Uंniv. Monthly, vol. 4, February, 1902. Meinzer, O. E., and Kelton, F. C., Geology and water resources of Sulphur Spring Valley, Ariz.: U. S. Geol. Survey Water-Supply Paper 320, pp. 57-62, 1913. Schwennesen, A. T., Ground water in San Simon Valley, Ariz. and N. Mex.: U. S. Geol. Survey Water-Supply Paper 425, pp. 1-35, 1917. 
A large territory extending from the vicinity of Globe eastward nearly to Gila Bonita Creek and northward as far as the Salt River divide drains into San Carlos River, which at San Carlos enters the Gila from the north.

\section{GIIA BASIN.}

The surface of the Gila Basin can be divided into sharply contrasting belts that run parallel to its axis. (See fig. 2.)

On the north and south sides of the basin, adjacent to the mountains, are belts of hilly country which stand higher than the middle of the basin and which have evidently been produced by the erosion of what were at one time smooth alluvial slopes extending from the mountains toward the middle of the basin. Inside these hilly belts are belts of lower country which are the remnants of a lake bottom that once extended across the axis of the basin. This lake apparently came into existence after the alluvial slopes had been considerably eroded. As a result of the large amount of sediment deposited in the lake its bottom became smooth and had only gentle slopes toward the middle of the basin. Although this former lake bottom has been eroded since the disappearance of the lake, it still forms a strong contrast to the more anciently dissected marginal belts.

Inside the belts formed by the remnants of the ancient lake bottom is the valley of Gila River, which was cut by the river after the lake disappeared. The parts of the ancient lake bottom adjacent to the river valley have become much dissected, and with reference to the valley they form a rugged upland.

The river valley in its course within the reservation nas an average width of 1 to $1 \frac{1}{2}$ miles. Farther up the river, between Solomonville and Fort Thomas, the valley is much wider, in some places reaching a width of 4 or 5 miles. The floor of the valley is formed of sediment deposited by the river in the trough channeled out of the lake beds.

The river valley may be divided into river channel, flood plain, and terraces. The valley contains a series of low terraces at successive levels, each bordered by a steep bank. (See section C-C', Pl. II.) These terraces have been formed by the continued lateral cutting and shifting of the river, together with slight downward cutting. The lowest flats, which are only 2 to 4 feet above the stream channel, are flooded during high stages of the river and therefore may properly be called the flood plain.

SAN CARLOS BASIN.

The San Carlos Basin, though not so well defined as the Gila Basin and of more irregular outline, has the same general types of topography.

The valley of the San Carlos, like that of the Gila, has been chan- neled out of the older sediments that filled the rock basin and is bor- 
dered by steep bluffs leading up to the dissected upland slopes that are underlain by these older sediments. The average width of the valley is from one-half to three-fourths of a mile. The valley floor; built up of recent sediments deposited by the river, has been terraced like that of the Gila.

San Carlos River is an intermittent stream which rises in several branches in the western part of the Ash Flat plateau and flows in a general westerly direction to Rice, where it turns due southward and flows in that direction for a distance of 12 miles to its junction with the Gila at San Carlos. Two large draws empty into it in the vicinity of Rice-Gilson Wash, which extends along the railroad from Globe and joins the San Carlos at Rice station, and MacMillan Wash, which comes in from the north and joins the San Carlos $1 \frac{1}{2}$ miles above Rice.

\section{GEOLOGY.}

\section{IGNFOUS ROCKS.}

The igneous rocks are represented chiefly in the mountain areas and in intervening parts of the plateau area north of the Gila Range, where large quantities of basalt have been poured out. Ash Flat, which lies between the Gila Range and the range to the north that forms the divide betwieen the Gila and Salt river drainage basins, is largely floored by basalt, apparently of recent age. To the south, east, and north of the Triplets basalt has been poured out over the Quaternary basin deposits. Tuffs and breccias, products of this same period of volcanic disturbance, are interbedded with the basalts. East of San Carlos River remnants of basalt occur at a number of places overlying the soft Quaternary deposits. These lava caps, which have served to protect the underlying sediments against erosion, have produced flat-topped mesas which stand above the unprotected, irregularly eroded surface surrounding them. The most conspicuous example is the Flatiron Mesa, 4 miles northwest of San Carlos.

\section{SEDIMENTARY ROCKB.}

\section{PRE-QUATERNARY ROCKS.}

The rock complex that forms the core of the mountain ranges along the margins of these basins comprises not only igneous rock but various kinds of hard sedimentary rocks. The mountain areas in which these sedimentary rocks occur were not examined, but, to judge from the character of the débris that the streams have brought down from the mountains into the valleys, limestones are relatively abundant, especially in the Gila Range. Sandstones and various metamorphic rocks were also noted. 


\section{QUATERNARY DEPOSITS.}

GEHERAL CHARACTER.

The oldest sediments in the Gila and San Carlos basins consist of sand, gravel, and coarser rock débris laid down by streams and derived from the pre-Quaternary rocks that form the floors of the basins and constitute the mountains along their margins. These deposits were first studied by G. K. Gilbert in 1873 and named by him the Gila conglomerate. ${ }^{1}$

On the eroded surface of the Gila conglomerate rests a series of well-stratified fine-grained soft sandstones, tuffs, marly clays, and limestones that were apparently deposited in a body of standing water and will in this report be referred to collectively as the lake beds.

The youngest sedimentary deposits in the area consist of the alluvium of the river valleys, which rests on the eroded surface of the lake beds. The river channels, flood plains, and terraces of the Gila and San Carlos river valleys are underlain by this material.

\section{GILA CONGLOMTRATE.}

In general character and method of deposition the Gila conglomerate is comparable to deposits commonly laid down by streams in the closed desert basins of the Southwest. Along the upper Gila, where Gilbert first examined it, he noted its continuity with the fill of the valleys that open into the Gila.

The Gila conglomerate in the San Carlos Indian Reservation consists of material ranging in coarseness from fine sand to boulders several feet in diameter. The materials are not firmly cemented but are coherent enough to form almost perpendicular cliffs in some localities. The conglomerate varies from place to place, both in the character of the constituent materials and in their arrangement, these features depending on the character of the rock from which the materials were derived and on the distance they have been transported. On the higher slopes along the flanks of the ranges the conglomerate is generally composed of angular material of various shapes and sizes jumbled together in.a confused mass without definite stratification. Near the axes of the basins, farther from the mountains, the materials are waterworn, sorted, and distinctly stratified. As is to be expected in deposits of this type, however, cross-bedding is common, and the individual beds lack persistency and grade from sand into gravel within short distances.

The Gila conglomerate crops out in a belt skirting the southern flanks of the Gila Range, in a similar belt adjacent to the northern

1 Gilbert, G. K., U. S. Geog. and Geol. Surveys W. 100th Mer. Rept., vol. 3, pp. 540-541, 1875. $124826^{\circ}-19-$ WSP $450 \mathrm{~A}-2$ 
edge of the Turnbull Range, and along the east side of the Pinal Range. (See Pl. II.) It is carved into a great number of rounded ridges that are separated from one another by deep gorges, forming a foothill belt that contrasts sharply with the rugged ranges above and also with the intricately dissected but generally even surface of the long, sweeping slopes that extend from the lower limit of the foothills to the edges of the river valleys.

The conglomerate belt that skirts the Gila Range on the north side of the basin extends across the east boundary of the reservation. Within the reservation it has an average width of about 3 miles and stretches from the east boundary northward about 15 miles and disappears beneath the lava flows centering about the Triplets.

The conglomerate belt adjacent to the Turnbull Range is 2 to 3 miles wide and extends westward from a locality 4 miles southwest of the box canyon to a point south of Bylas. Beyond this point it was not traced, but it was seen to narrow considerably and to sweep southward along the eastern flanks of Mount Turnbull. At the upper margin it laps up against the range at an average altitude of about 4,200 feet. Its general surface slopes at the rate of about 450 feet to the mile, and its lower limit corresponds approximately to the 3,300 -foot contour.

The conglomerate area on the west side of the San Carlos Basin extends northward from the box canyon along the flanks of the eastern ridges of the Pinal Mountains. From the box canyon the conglomerate is easily traced northward for 5 miles by its characteristic topography. Farther north the topographic distinction becomes less marked, and the contact between the conglomerate and the overlapping sandstone is not easily traced.

As no complete sections were exposed the thickness of the formation could not be determined, but on the basis of the position and slope of the rock floor as determined in some of the canyons, and of the position and slope of the original upper surface of the formation as determined by the ridges of conglomerate, the maximum thickness of the Gila conglomerate in the middle of the Gila Basin is estimated to be not less than 1,000 feet. (See sections, Pl. II.)

\section{IAKE BEDS.}

Upon the eroded surface of the Gila conglomerate was deposited a series of sandstones, tuffs, limestones; and marly clays which will be referred to collectively as the lake beds, for they were evidently deposited in a body of standing water. This formation underlies the central and intermediate parts of the Gila and San Carlos basins, where it is at the surface except in the river valleys. (See Pl. II.)

The sandstone member of this formation is a soft, fine-grained, well-stratified buff sandstone, interbedded with thin layers or partings of a hard indurated sandstone of similar composition but usually 
of a somewhat coarser texture. Good sections are exposed in the bluffs that border the valley of Gila River and in the numerous canyons that open into the valley.

The other members of the formation consist of interbedded lightcolored tuffs, buff marly clays, and light-gray limestones, all of which are found principally in the region extending from the Triplets northward to San Carlos River and southward to the Gila. These rocks are prominently displayed in the bluffs on the east side of the San Carlos Valley between San Carlos and Rice and on both sides of the valley above Rice.

The maximum thickness of the lake beds within the reservation is not known, as no complete sections are exposed. In the construction of the geologic sections (Pl. II) an estimate of the thickness of these beds was made which is believed to be reasonable. A surface passing through the crests of the ridges formed by the Gila conglomerate was assumed to represent the original surface of the Gila conglomerate. By projecting this surface beneath the lake beds and allowing for a gradual decrease in slope toward the axis of the basin the writer determined the approximate position of the surface upon which the lake beds would have been deposited if there had been no previous erosion of the conglomerate. In section D- $\mathrm{D}^{\prime}$, Plate II, for instance, the general slope of the surface of the Gila conglomerate where it crops out on the south side of the basin is shown as between $4 \frac{1}{2}^{\circ}$ and $5^{\circ}$, or about 450 feet to the mile. This surface projected beneath the lake beds, with allowances for decrease of slope northward, gives an elevation of approximately 2,000 feet above sea level at the axis of the basin, or about 600 feet below the surface of the river valley. Similarly, section $\mathrm{C}-\mathrm{C}^{\prime}$, which crosses the valley of Gila River between Calva and Dewey Flat, shows the bottom of the lake beds to be about 600 feet below the surface at the axis of the basin. The lake beds at San Carlos (section B-B') are estimated to be about 800 feet thick, and those at Peridot (section $\mathrm{A}-\mathrm{A}^{\prime}$ ), in the valley of San Carlos River, about 700 feet. If the conglomerate was deeply dissected before deposition began the maximum thickness of the lake beds may be greater.

The lake beds generally have a slight dip toward the river valleys. On the south side of the Gila the dip is from $1 \frac{1}{2}^{\circ}$ to $2^{\circ} \mathrm{N}$. West of San Carlos River the beds have a slight dip toward the east. North of the Gila and east of the San Carlos they appear to be nearly horizontal.

The formation seems to have undergone little folding or faulting. Slight folding and minor faulting were noted in the limestone beds exposed in the bluffs of Gila River just east of its junction with the San Carlos. An east-west fault was also noted in the vicinity of a lava flow 2 miles west of Flatiron Mesa, on the west side of the San 
Carlos Basin. Faulting has probably occurred in connection with the disturbances that accompanied the outpouring of the lava at other places.

\section{ArrUVIUK.}

The youngest sedimentary deposit in the area is the alluvium of the Gila and San Carlos valleys. It consists of sand and gravel laid down in troughs channeled out of the lake beds. Most of the fine material has been deposited by the rivers and resembles the material that forms the bottoms of the present channels. The gravel has for the most part been brought down through the arroyos opening into the valleys from the sides.

\section{QUATERNARY HISTORY.}

The Quaternary history of the region can be outlined as follows:

1. Aggradation in the rock troughs, resulting in the deposition of about 1,000 feet of gravelly alluvium and the construction of large, steep alluvial slopes.

2. Erosion of the alluvial slopes.

3. Submergence of the lower parts of the alluvial slopes by a lake. Deposition of sand, tuff, and other sediments in the lake to a maximum depth of probably 800 feet. Continued erosion of the parts of the slopes that were not submerged.

Volcanism, resulting in the outpouring of basalt, the deposition of tuff, and minor faulting and folding, at least chiefly, in the later part of the period covered by epochs Nos. 1, 2, and 3, but may not have been confined to No. 3 .

4. Disappearance of the lake. The cause of the formation of this lake and that of its disappearance are not known. Excavation of the valleys by Gila and San Carlos rivers in the old lake bottom, and intricate dissection of the lake bottom near the river valleys.

5. Partial refilling of the river valleys through deposition by the streams, followed by slight changes in stream grade that resulted in the formation of a series of low terraces. Continued erosion of the lake bottom.

Erosion of the older alluvial slopes was practically continuous after epoch No. 1; the erosion of the mountain ranges continued throughout the period, and the erosion of the lava beds began immediately after their extrusion and continued without interruption.

\section{CLASSIFICATION OF IANDS.}

The lands of the Gila and San Carlos valleys may be classed as arable or nonarable on the basis of their suitability for farming and irrigation if a water supply is provided. Their suitability for this purpose depends in part on their topography and the quality of their soil. 


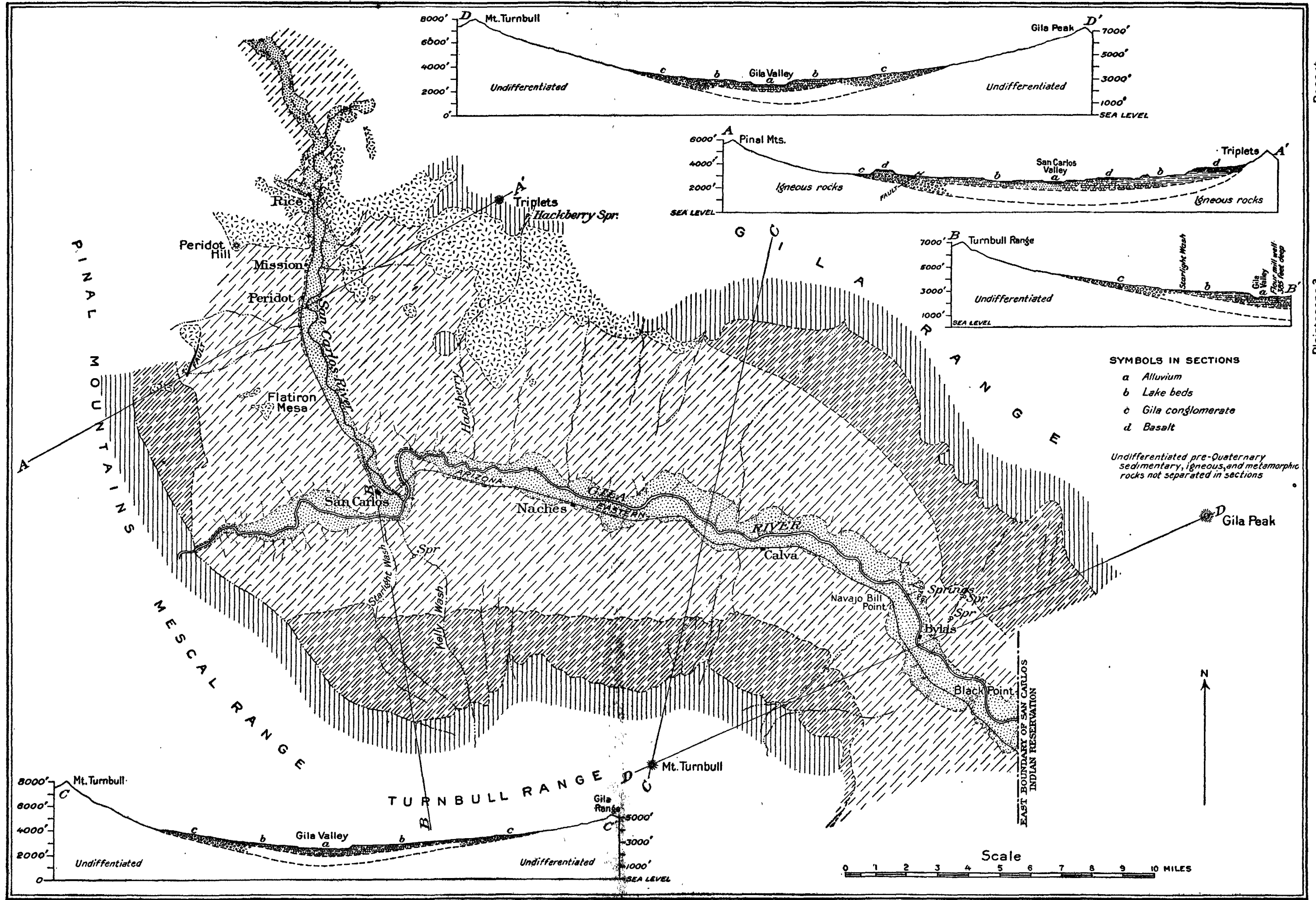



All the lands that lie at a sufficient elevation above the riven to be out of reach of floods, whose soil is satisfactory, and whose surface. can be prepared for cultivation and the application of irrigating. water with a reasonable amount of labor and expense have been classified as arable lands. These lands are for the most part on the low terraces. The soils are light and well drained. Among the native plants growing on the uncleared tracts mesquite and cat-claw predominate, but cottonwood trees are also common.

In the valley of Gila River above the proposed San Carlos reservoir site there is, as nearly as could be determined, 4,595 acres of land which may be classed as arable. This area includes 421 acres irrigated and farmed in the Bylas district in 1913. (See Pl. III.)

In the main valley of San Carlos River above the proposed reservoir site the amount of arable land, including that irrigated under the present system, is approximately 1,840 acres. (See Pl. IV.)

The nonarable lands consist of the river channels, the flood plains, or river bottoms, and the terrace lands near the edges of the valley where the surface is too uneven or the soil is too gravelly for farming. Cottonwoods, willows, and certain unidentified water-loving shrubs grow as thickets on the flood plains. The higher gravelly tracts near the bluffs are the favorite habitat of the creosote brush and members of the cactus family.

Along Gilson Wash, which enters the valley of San Carlos River at Rice, and MacMillan Wash, which enters it $1 \frac{1}{2}$ miles above Rice, are numerous small tracts of land that could probably be successfully. farmed if water were available, but these lands have not been included with the area classed as arable.

\section{SURFACE WATER SUPPIY.}

The only streams in the area under discussion that offer a possible source of water supply in sufficient quantities for irrigation are Gila River and San Carlos River. Both streams head in areas where melting snow furnishes considerable flow during the early spring months, but about the last of April the snow disappears and the streams fall rapidly, reaching a minimum about the first of July, when the summer rains ordinarily begin. The most severe droughts, however, occur during July and August in years when the summer rains fail or are not of sufficient intensity to swell the streams.

The total annual run-off of Gila River, even during the lowest years, is undoubtedly more than sufficient to irrigate all the arable land in the reservation, but without storage it is of little value, because it passes during the months when it is least needed or in floods so intense that it can not be conducted to the land without unduly expensive diversion dams. 
San Carlos River is ordinarily dry for a considerable part of eàch year, but.if the total run-off during normal years could be economically stored it would probably be sufficient to irrigate several thousand acres of land. It is doubtful, however, if feasible storage sites exist on this stream.

The following tables give the essential results of measurements of stream flow on Gila River in the vicinity of San Carlos and on San Carlos River that have been made by the United States Geological Survey. The records of flow on Gila River at San Carlos from 1899 to 1905 are of exceptional value and interest, in that they cover a period of the most severe drought that has been experienced in the history of modern agricultural development in Arizona.

\section{GILA RIVER AT SAN CARLOS, ARIZ.}

Locatron.-Half a mile south of Śan Carlos Indian Agency at San Carlos, Gila County, half a mile below San Carlos River, and about 7 miles above dam site in box canyon.

Records avariable.-July 11, 1899, to November 27, 1905 (incomplete). From August 17, 1910, to February 5, 1911, a station was maintained just below the Arizona Eastern Railroad bridge and half a mile above San Carlos River. Because of insufficient data discharges have not been computed for this station. For discharge measurements and gage heights see Water-Supply Papers 289 and 309.

GAGE.-Inclined staff on right bank.

DischaRGE MEASUREMENTs.-Made from cable a short distance above gage.

ChanNel and control. - Sandy and badly shifting.

Extremes of Discharge.-Discharge 'varies from zero flow to enormous floods, probably exceeding 100,000 second-feet. No accurate measurements of extreme floods have been made.

Drversions.-Water for irrigating several thousand acres was diverted above the station for use in the Solomonville and Duncan valleys. A small amount of water (probably not exceeding 5 second-feet at any time) was also diverted just above the gage for.irrigating lands within the reservation.

Accuracy.-Results liable to considerable error, particularly during low stages, on account of shifting channel and control. 
Monthly discharge of Gila River at San Carlos, Ariz., for 1899-1905.

\begin{tabular}{|c|c|c|c|c|}
\hline \multirow{2}{*}{ Month. } & \multicolumn{3}{|c|}{ Discharge in second-feet. } & \multirow{2}{*}{$\begin{array}{l}\text { Run-off in } \\
\text { acre-foet. }\end{array}$} \\
\hline & Maximum. & Minimum. & Mean. & \\
\hline $\begin{array}{l}\text { July } 11-31 \ldots \ldots \ldots \\
\text { August } \ldots \ldots \ldots \ldots \\
\text { September } \ldots \ldots \ldots \ldots \\
\text { October } 1-18 \ldots \ldots\end{array}$ & $\begin{array}{r}11,000 \\
2,740 \\
6,860 \\
300\end{array}$ & $\begin{array}{r}195 \\
90 \\
75 \\
75\end{array}$ & $\begin{array}{r}1,760 \\
408 \\
416 \\
+\quad 143\end{array}$ & $\begin{array}{r}73,300 \\
25,100 \\
24,800 \\
5,110\end{array}$ \\
\hline The period.. & $\ldots$ & ...... & ..... & 128,000 \\
\hline $\begin{array}{l}\text { April } 4-30 \ldots \ldots \ldots \ldots \\
\text { May } \ldots \ldots \ldots\end{array}$ & $\begin{array}{r}75 \\
4.5 \\
.8 \\
.5 \\
2,750 \\
6,900 \\
102 \\
2,900 \\
118\end{array}$ & $\begin{array}{r}3.5 \\
.9 \\
.3 \\
.1 \\
1.0 \\
25 \\
36 \\
10 \\
66\end{array}$ & $\begin{array}{r}5.7 \\
2.4 \\
.6 \\
.3 \\
198^{.3} \\
987 \\
60.0 \\
177 \\
102\end{array}$ & $\begin{array}{r}305 \\
148 \\
36 \\
18 \\
12,200 \\
55,800 \\
3,690 \\
10,500 \\
6,270\end{array}$ \\
\hline The period....... & ........ & .......... & $\ldots \ldots \ldots$ & 89,000 \\
\hline 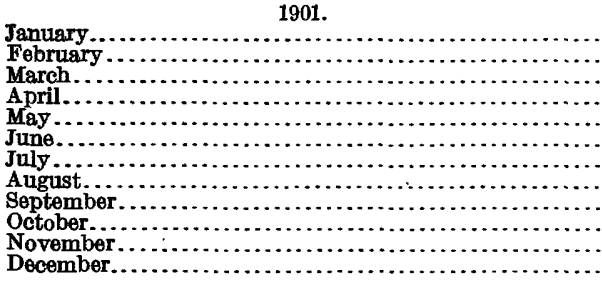 & $\begin{array}{r}1,150 \\
2,110 \\
1,080 \\
155 \\
8 \\
6 \\
3,600 \\
1,870 \\
1,700 \\
460 \\
630 \\
155\end{array}$ & $\begin{array}{r}36 \\
420 \\
155 \\
6 \\
4 \\
0^{-3} \\
67 \\
18 \\
10 \\
133 \\
94\end{array}$ & $\begin{array}{c}141 \\
1,110 \\
426 \\
59.3 \\
5.5 \\
2.6 \\
377 \\
482 \\
212 \\
67.5 \\
223 \\
110\end{array}$ & $\begin{array}{r}8,670 \\
61,600 \\
26,200 \\
3,530 \\
338 \\
155 \\
23,200 \\
29,600 \\
12,600 \\
4,150 \\
13,300 \\
6,760\end{array}$ \\
\hline The year.......... & 3,600 & $\mathbf{0}$ & 262 & 190,000 \\
\hline 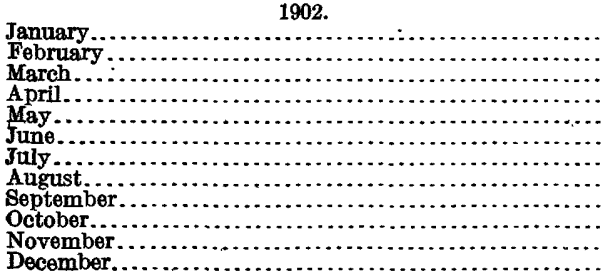 & $\begin{array}{r}94 \\
57 \\
26 \\
2 \\
0 \\
0 \\
400 \\
1,820 \\
340 \\
4 \\
30 \\
2,750\end{array}$ & $\begin{array}{r}50 \\
26 \\
8 \\
0 \\
0 \\
0 \\
0 \\
0 \\
40 \\
0 \\
0 \\
0\end{array}$ & $\begin{array}{r}79.1 \\
45.9 \\
13.5 \\
.1 \\
.0 \\
.0 \\
28.2 \\
407 \\
114 \\
1.1 \\
1.2 \\
583\end{array}$ & $\begin{array}{r}4,860 \\
2,550 \\
830 \\
4 \\
0 \\
0 \\
1,730 \\
25,000 \\
6,780 \\
8 \\
71 \\
35,800\end{array}$ \\
\hline The year... & 2,750 & 0 & 107 & 77,600 \\
\hline 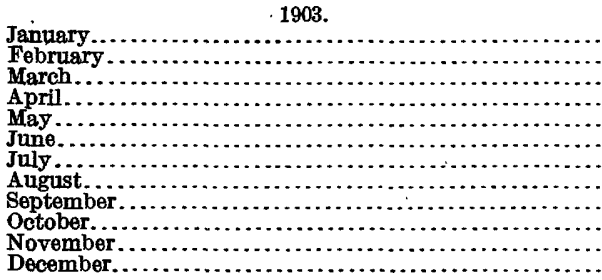 & $\begin{array}{r}360 \\
73 \\
110 \\
147 \\
8 \\
670 \\
575 \\
3,570 \\
2,150 \\
405 \\
78 \\
43\end{array}$ & $\begin{array}{l}79 \\
43 \\
10 \\
9 \\
.6 \\
.4 \\
.2 \\
1 \\
16 \\
38 \\
42 \\
22\end{array}$ & $\begin{array}{c}169 \\
53.3 \\
35.7 \\
50.6 \\
2.2 \\
107 \\
53.3 \\
963 \\
223 \\
106 \\
55.4 \\
35.5\end{array}$ & $\begin{array}{r}\mathbf{1 0 , 4 0 0} \\
\mathbf{2}, \mathbf{9 6 0} \\
2,200 \\
3,010 \\
\mathbf{1 3 5} \\
\mathbf{6}, \mathbf{3 7 0} \\
\mathbf{3}, \mathbf{2 8 0} \\
\mathbf{5 9}, \mathbf{2 0 0} \\
\mathbf{1 3}, \mathbf{3 0 0} \\
\mathbf{6 , 5 2 0} \\
\mathbf{3 , 3 0 0} \\
\mathbf{2 , 1 8 0}\end{array}$ \\
\hline The year........... & 3,750 & .2 & 156 & 113,000 \\
\hline
\end{tabular}


Monthly discharge of Gila River at San Carlos, Ariz., for 1899-1905-Continued.

\begin{tabular}{|c|c|c|c|c|}
\hline & \multicolumn{3}{|c|}{ Discharge in second-feet. } & \multirow{2}{*}{$\begin{array}{l}\text { Run-off in } \\
\text { acre-feet. }\end{array}$} \\
\hline & Maximum. & Minimum. & Maan. & \\
\hline 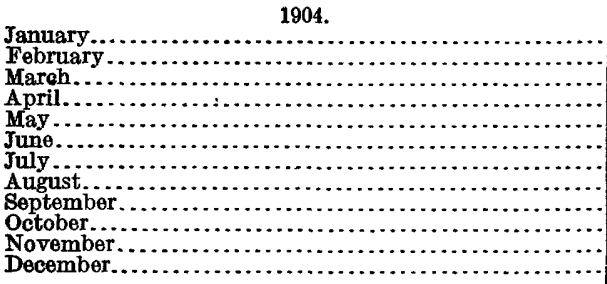 & $\begin{array}{r}36 \\
48 \\
15 \\
12 \\
115 \\
0 \\
1,580 \\
3,200 \\
1,300 \\
5,870 \\
210 \\
660\end{array}$ & \begin{tabular}{r|}
27 \\
17 \\
9 \\
2 \\
0 \\
0 \\
0 \\
240 \\
20 \\
20 \\
42 \\
31
\end{tabular} & $\begin{array}{r}31.7 \\
32.6 \\
11.0 \\
5.3 \\
8.7 \\
0 \\
143 \\
952 \\
232 \\
825 \\
112 \\
306\end{array}$ & $\begin{array}{r}1,950 \\
1,880 \\
676 \\
315 \\
535 \\
0 \\
8,790 \\
58,500 \\
13,800 \\
50,700 \\
6,660 \\
18,800\end{array}$ \\
\hline The year........ & 5,870 & $\mathbf{0}$ & 224 & 163,000 \\
\hline 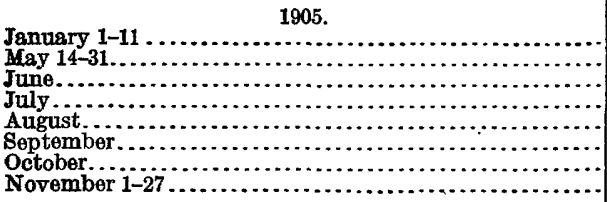 & $\begin{array}{r}7,000 \\
1,400 \\
675 \\
740 \\
1,090 \\
1,650 \\
705 \\
6,150\end{array}$ & $\begin{array}{r}120 \\
440 \\
30 \\
5 \\
110 \\
68 \\
28 \\
58\end{array}$ & $\begin{array}{c}1,290 \\
949 \\
255 \\
99.6 \\
441 \\
544 \\
149 \\
1,100\end{array}$ & $\begin{array}{r}28,100 \\
33,900 \\
15,200 \\
6,120 \\
27,100 \\
32,400 \\
9,160 \\
58,900\end{array}$ \\
\hline
\end{tabular}

Noxw.-No record for the periods Oct. 19, 1899, to Apr. 3, 1900, and Jan. 12 to May 13, 1905.

GILA RIVER NEAR SAT CARIOS, ARIZ.

Locatron.-One mile above dam site in box canyon, in San Carlos Indian Reservation, about 6 miles below San Carlos Indian Agency, Gila County.

Records avamable.-April 29, 1914, to September 30, 1917.

GAGE.-Stevens water-stage recorder on left bank about 1 mile above dam site.

Discharge Measurements.-Made by wading near gage or from cable about 1 mile above gage.

Channel AND control. - Channel composed of sand, gravel, and boulders. A semipermanent control is formed by rapids over heavy boulders just below gage. Control shifts somewhat because of sand filling in and washing out from crevices between the boulders.

Extremes of discharge.-1914-1917: Maximum stage 25.5 feet January 20, 1916 (approximate discharge, determined from extension of rating curve, 92,000 second-feet); minimum stage 0.15 foot, July 1, 1914 (discharge, 1 second-foot).

Diversions.- Water for irrigating about 30,000 acres is diverted from river in valley just above station. At times this diversion reduces the low flow practically to zero at the station. About 7,000 acres is irrigated from this stream above the station at Guthrie.

ACCURACY.-Results fair except for extremely high or low stages or for estimated periods. (See footnote to monthly discharge table.) 
Monthly discharge of Gila River near San Carlos, Ariz., for years ending Sept. 30, 191.41917.

\begin{tabular}{|c|c|c|c|c|}
\hline \multirow{2}{*}{$\begin{array}{r}\mathbf{M o}_{0} \\
-\end{array}$} & \multicolumn{3}{|c|}{ Discharge in second-feet. } & \multirow{2}{*}{$\begin{array}{l}\text { Run-off (in } \\
\text { acre-feet). }\end{array}$} \\
\hline & Maximum. & Minimum. & Mean. & \\
\hline \multirow{2}{*}{ 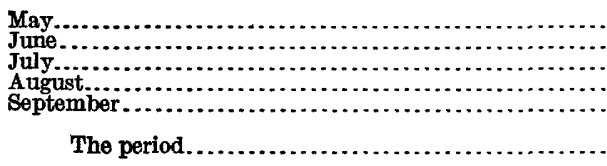 } & $\begin{array}{r}405 \\
2,380 \\
3,220 \\
2,430\end{array}$ & $\begin{array}{r}3 \\
1 \\
291 \\
120\end{array}$ & $\begin{array}{r}8 \\
725 \\
968 \\
1,080 \\
612\end{array}$ & $\begin{array}{r}492 \\
4,310 \\
59,500 \\
66,400 \\
36,400\end{array}$ \\
\hline & & & & 167,000 \\
\hline 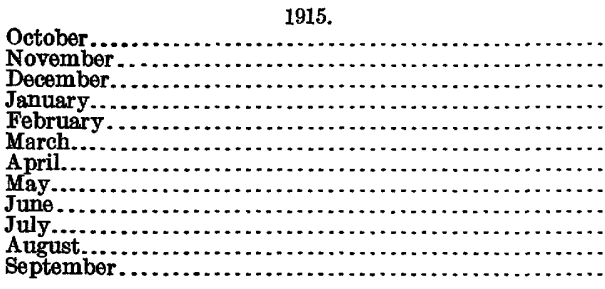 & $\begin{array}{r}\begin{array}{r}6,150 \\
\mathbf{3}, 220\end{array} \\
\hdashline \ldots \ldots \\
\hdashline \ldots .\end{array}$ & 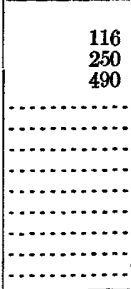 & $\begin{array}{r}1,170 \\
781 \\
6,180 \\
2,420 \\
3,950 \\
3,570 \\
3,870 \\
1,130 \\
193 \\
907 \\
500 \\
267\end{array}$ & $\begin{array}{r}71,990 \\
46,500 \\
380,000 \\
149,000 \\
219,000 \\
220,000 \\
230,000 \\
69,500 \\
11,500 \\
55,800 \\
30,700 \\
15,900\end{array}$ \\
\hline 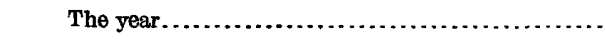 & & & 2,100 & $1,500,000$ \\
\hline 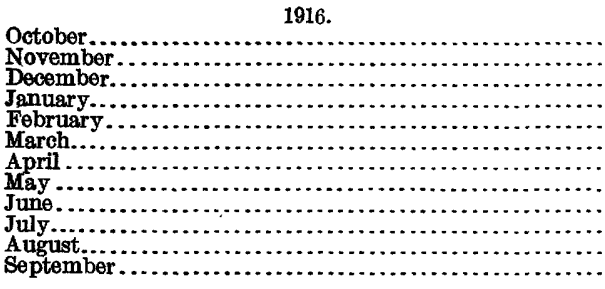 & $\begin{array}{r}\begin{array}{r}164 \\
134 \\
387\end{array} \\
\ldots \ldots \ldots \\
2,410 \\
968 \\
121 \\
190 \\
1,770 \\
2,670\end{array}$ & $\begin{array}{r}26 \\
26 \\
130 \\
387 \\
3 \times \ldots . . \\
533 \\
127 \\
17 \\
12 \\
144 \\
128\end{array}$ & $\begin{array}{c}66.7 \\
71.5 \\
222 \\
12,800 \\
3,290 \\
2,890 \\
1,080 \\
403 \\
57.3 \\
87.6 \\
788 \\
720 .\end{array}$ & $\begin{array}{r}4,100 \\
4,250 \\
13,600 \\
787,000 \\
189,000 \\
178,000 \\
64,300 \\
24,800 \\
3,410 \\
5,390 \\
48,500 \\
42,800\end{array}$ \\
\hline The year. . & $\ldots \ldots$ & 12 & 1,890 & $1,370,000$ \\
\hline 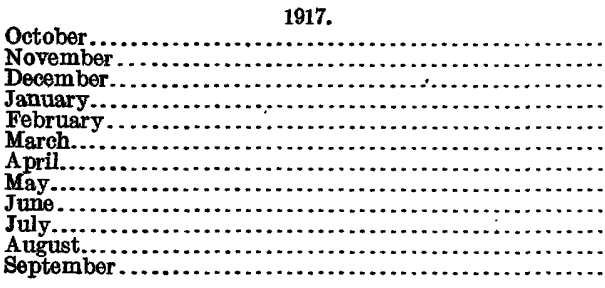 & $\begin{array}{r}33,500 \\
822 \\
444 \\
14,400 \\
1,550 \\
1,910 \\
938 \\
\ldots \ldots . \\
1,050 \\
827 \\
\ldots . . \\
\end{array}$ & $\begin{array}{r}103 \\
330 \\
316 \\
328 \\
514 \\
418 \\
190 \\
72 \\
15 \\
14 \\
57 \\
\ldots . .\end{array}$ & $\begin{array}{c}3,240 \\
442 \\
347 \\
1,850 \\
964 \\
774 \\
482 \\
152 \\
34.8 \\
187 \\
221 \\
48.2\end{array}$ & $\begin{array}{r}199,000 \\
26,300 \\
21,300 \\
114,000 \\
53,500 \\
47,600 \\
28,700 \\
9,350 \\
2,070 \\
11,500 \\
13,600 \\
2,870\end{array}$ \\
\hline The year.. & 33,500 & 14 & 732 & 530,000 \\
\hline
\end{tabular}

NOTE.-Mean discharge for May and December, 1914; January to September, and December, 1915; January to March, and December, 1916; and May and September, 1917 estimated or partly estimated by com. parison with records at other stations on this stream.

\section{SAI CARLOS RIVER AT SAT CARLOS, ARIZ.}

Locamon.-Opposite railroad station at San Carlos, Graham County, in San Carlos Indian Reservation, about half a mile above junction with Gila River.

Dratnage area.-Not measured.

Records avatraBle.-August 17, 1910, to.January 12, 1911, ${ }^{1}$ and April 1, 1914, to September 30, 1915, when station was discontinued.

1 Discharge not computed from Aug. 17, 1910, to Jan. 12, 1911. For discharge measurements and gage heights see Water-Supply Papers 289 and 309. 
GAGE.-Stevens water-stage recorder on left bank. The original gage, which was used from August 17, 1910, to January 12, 1911, was a vertical staff fastened to right pier of railroad bridge, downstream end.

Discharge measurements.-Made by wading or from cable at gage.

Channel and control.- Sand, badly shifting at all stages. Section flat and nonsensitive.

Extremes of Discharat.-Stream dry a part of each year. July 26, 1915, a heavy flood occurred, covering the surrounding lowlands. Discharge not determined.

Diversions.-No record of any diversions, although a small amount was probably diverted above the gage for irrigation.

Accuracr.-Results poor because of shifting control and insufficient discharge measurements.

Monthly discharge of San Carlos River at San Carlos, Ariz., from Apr. 1, 1914, to Sept. 30, 1915.

\begin{tabular}{|c|c|c|c|c|}
\hline \multirow{2}{*}{ Month. } & \multicolumn{3}{|c|}{ Discharge in second-feet. } & \multirow{2}{*}{$\begin{array}{l}\text { Run-off in } \\
\text { acre-feet. }\end{array}$} \\
\hline & Maximum. & Minimum. & Mean. & \\
\hline 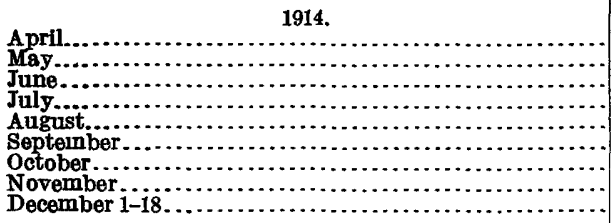 & $\begin{array}{r}0 \\
0 \\
21 \\
165 \\
145 \\
90 \\
375 \\
290 \\
150\end{array}$ & $\begin{array}{r}0 \\
0 \\
0 \\
0 \\
0 \\
10 \\
10 \\
25 \\
40\end{array}$ & $\begin{array}{r}0 \\
0 \\
2.1 \\
12.8 \\
47 \\
32.3 \\
59 \\
60 \\
63\end{array}$ & $\begin{array}{r}0 \\
0 \\
125 \\
762 \\
2,800 \\
1,920 \\
3,630 \\
3,570 \\
2,250\end{array}$ \\
\hline The period....... & 375 & 0 & 292 & 15,100 \\
\hline 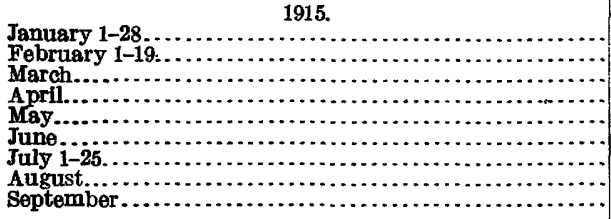 & $\begin{array}{r}145 \\
210 \\
160 \\
190 \\
132 \\
155 \\
0 \\
\hdashline \ldots . .\end{array}$ & $\begin{array}{r} \\
40 \\
5 \\
7 \\
7 \\
6 \\
2 \\
2 \\
0 \\
0 \\
0\end{array}$ & $\begin{array}{c}79 \\
128 \\
97 \\
46 \\
36 \\
2.6 \\
0 \\
a 15 \\
a 5\end{array}$ & $\begin{array}{r}4,390 \\
4,820 \\
\mathbf{5}, 960 \\
\mathbf{2}, 740 \\
\mathbf{2}, 210 \\
155 \\
0 \\
920 \\
\mathbf{3 0 0}\end{array}$ \\
\hline
\end{tabular}

$a$ Estimated.

Nore.-Floods above the limit covered by the rating eurve occurred during the period Dec. 19-30, 1914, Jan. 29-31, Feb. 20-22, and July 26-31, 1915. Discharge Dec. 31, 1914, 150 second-feet. Mean discharge Feb. 23-28, 1915, 15.7 second-feet.

\section{PRESENT IRRTGATION.}

All irrigation on the reservation in 1914 was done with water from the Gila and San Carlos rivers, diverted into the main canals by brush and earth dams thrown across the channels. These dams are temporary affairs that wash out at each flood and must be rebuilt at the beginning of each irrigating season and perhaps several times during the season. They are necessarily low and are too frail to impound the water and raise it much above its natural level, so that the intake of the ditch can be little higher than the bottom of the channel. This condition allows little opportunity for the silt to settle before the water is taken into the canals. Consequently the canals, especially those on the Gila, become choked with silt and must 
frequently be dug out. Flood waters discharging into the canals through gullies from the sides of the valley also deposit much silt and often destroy sections of the canals by cutting across them.

Permanent dams that could withstand the floods would save much expense and also relieve the present water shortage to some extent, for much water is now lost by seepage through the temporary dams, even when the rivers are low. On account of the unstable character of the bottom and sides of the channels, however, permanent dams may not be practicable on Gila River. On the upper San Carlos a suitable site for a permanent dam could probably be found, but whether the additional land that could be irrigated with the water saved by a permanent dam would warrant its construction is not certain.

The enlargement of the present irrigation system on Gila River to include more of the arable lands in the valley would require the construction of canals at higher levels than those now in use. If permanent dams are not practicable the construction of high-level canals would necessitate either carrying the ditch head much farther up the river and outside of the reservation, or else pumping from the river into the high-level canals.

The most serious drawback to the present irrigation system is the inadequacy of the water supply during certain months of the year. Gila and San Carlos river's are usually lowest in May, June, and July, the months during which water is most needed. It is not unusual for these streams to dry up entirely at times during these months, so that it becomes necessary to scrape out holes in the sand and gravel of the channels to provide water for stock. According to the stream-gaging records of the United States Geological Survey for 1914 no water passed the gaging station on San Carlos River at San Carlos during April and May, but in June 125 acre-feet and in July 762 acre-feet passed the station. At the gaging station above the box canyon on the Gila the average flow for the first 22 days after the automatic gage was in operation, from May 27 to June 17, was 18 acre-feet per day. As these records were obtained below the irrigated districts of the reservation they do not show the amount of water taken out by ditches.

The yearly cost of keeping up the ditches and diversion dams on the reservation is from $\$ 1,800$ to $\$ 2,000$. In 1913 the expenditure in preparation for the season's irrigation was $\$ 1,908$, according to the statement of the superintendent, A. L. Lawshe. The total area irrigated, according to $\mathrm{Mr}$. Lawshe, was 1,428 acres, of which 421 acres was in the Bylas district, 469 acres in the San Carlos district, and 538 acres in the Peridot district. The cost per acre was therefore $\$ 1.34$. 


\section{SHAILOW GROUND WATER.}

\section{OCCURRENCE AND QUANTITY.}

Water is found at shallow depths in the Recent alluvial fill of the Gila and San Carlos valleys. Most of the wells are on the low terraces above the stream channels. Most wells dug by, the Indians for domestic water supplies are not more than 15 or 20 feet deep, but several constructed by white settlers on higher ground are deeper. The Rice school well, at the base of the bluffs on the north side of San Carlos Valley (No. 3, Pl. IV), is 36 feet deep and has a depth to water of 32 feet. Two large dug wells at the flour mill at San Carlos are 30 and 32 feet deep. The well at the railroad station at Calva, near the foot of the bluffs on the south side of Gila Valley (No. 13, $\mathrm{Pl}$. III), is 75 feet deep, and the water table here is 45 feet below the surface.

The shallow wells on the level arable terraces end in sand and fine gravel similar to the material in the present stream channels. The general correspondence of the water level in the wells with the level of the water in the streams indicates that the alluvium is saturated about to the stream level.

The water is supplied by percolation from the rivers, by water discharged into the valleys through tributary arroyos, and by direct rainfall on the valleys. The principal contributions are probably made by percolation of stream water into the bottoms and sides of the river channels. Second in importance are contributions made by tributary arroyos, a part of whose water sinks into the gravel near the edges of the valleys. The amount of water contributed by direct rainfall is relatively small. The rapidity with which water withdrawn from wells is replenished depends on the porosity and continuity of the water-bearing beds and the location of the wells with respect to the streams. Wells close to the stream channels will probably yield more freely than wells farther back, at a greater distance from the principal source of supply. Where large quantities of water are required it is therefore generally not advisable to sink wells at very great distances from the streams.

The lake beds, which underlie the Recent alluvium, yield some water but do not constitute good water-bearing material. The large dug wells at the San Carlos flour mill, on the gently sloping ground above the San Carlos bottoms, penetrate about 15 feet of coarse sand and gravel and then pass into the lake beds. The upper sands and gravels are above the water level and are therefore dry, and the water is said to come out of thin "clay" seams in soft fine-grained sandstone. The wells are about 30 feet deep and have an aggregate cross-sectional area of about 1,400 square feet. In summer about 50,000 gallons of water is pumped from them during a 10-hour day. 
At this rate these large wells are soon pumped down, and in order to continue pumping it is necessary to put into operation a syphon connecting the large wells with a well on the terrace of San Carlos River. When pumping is continuous this well, which is only 10 feet deep and 8 by 8 feet in cross section and which ends in Recent thinvium, furnishes most of the water.

A number of years ago two wells were drilled from the bottom of the larger of the two wells at the flour mill in the hope of getting an increased supply from a deeper stratum. One of these wells reached a depth of about 115 feet, and the other was sunk to a depth of 385 feet below the surface. Both wells were failures, although in the 385 -foot well a small supply of water was obtained at 85 feet. All the way down these wells were in the same fine-grained sandstoneprobably belonging to the lake beds-found in the lower parts of the dug wells.

\section{QUALITY.}

The mineral character of waters from wells and from Gila River is shown in Tables 1 and 2. The samples whose analyses are given in Table 1 were collected by the writer in the course of the field investigation. Table 2 gives the results of analyses. of waters from a number of shallow test wells put down in the Gila Valley several years ago under the direction of James W. Martin, superintendent of irrigation for the Indian Office.

In samples $1,9,12,13$, and 14 (Table 1), which represent waters from shallow wells in the Gila Valley above the proposed San Carlos reservoir site, the amount of total solids ranges from 1,330 to 2,412 parts per million. Samples $9,12,13$, and 14 are very high in their content of chlorine, one of the constituents of sodium chloride or common salt, ordinarily referred to as one of the "white alkalies." These waters are practically worthless for irrigation under ordinary conditions. Sample 1 contains less sodium chloride but contains a prohibitive amount of sodium carbonate or "black alkali," which is even more harmful than white alkali. The sample of water from Gila River at the canal intake is representative of the water now used for irrigation on the reservation. Comparison with the well waters shows that it contains less than half as much white alkali. The fact that it has been used successfully for many years for the irrigation of crops in the Gila Valley is sufficient proof of its value as an irrigating water. The effects of its continued use, however, are shown by the alkali spots that appear in the alfalfa fields, and it is questionable whether the crops could endure a much greater amount of these salts. A doubling of the amount of alkali, which would result from the use of well waters such as the analyses represent, would probably prove fatal to most crops, even under the most favorable conditions of soil and drainage. 
The sample from the pumping plant at San Carlos (Table 1) is a mixed water from wells at the flour mill and a well about 500 feet northeast of the flour mill, on the San Carlos River bottoms. This water contains less soluble salts than any of the other well waters that were analyzed. It contains a moderate amount of white alka.li and a small amount of the more injurious black alkali. As an irrigating water it may be classed as fair, and in its probable effects on crops $i i$ is comparable to the water from Gila River.

Unfortunately no analyses of well waters from the San Carlos Valley are available. A sample thought to be fairly representative of well waters in the San Carlos Valley was obtained from a driven well near the river at the new steel bridge across the San Carlos. The sample was too small for a complete analysis, however, and therefore no report on this water was obtained. 
SAN CARLOS INDIAN RESERVATION, ARIZ.

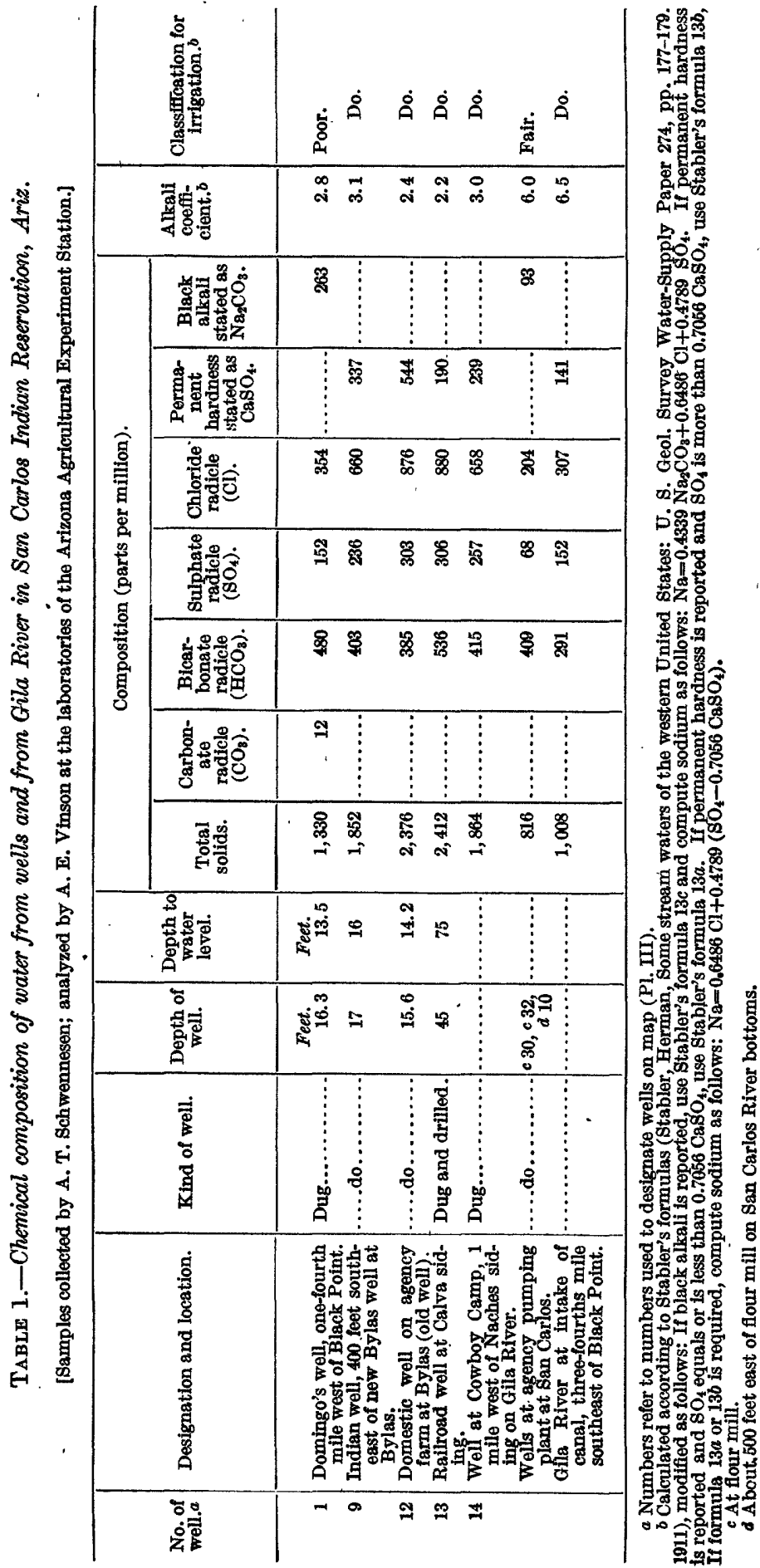




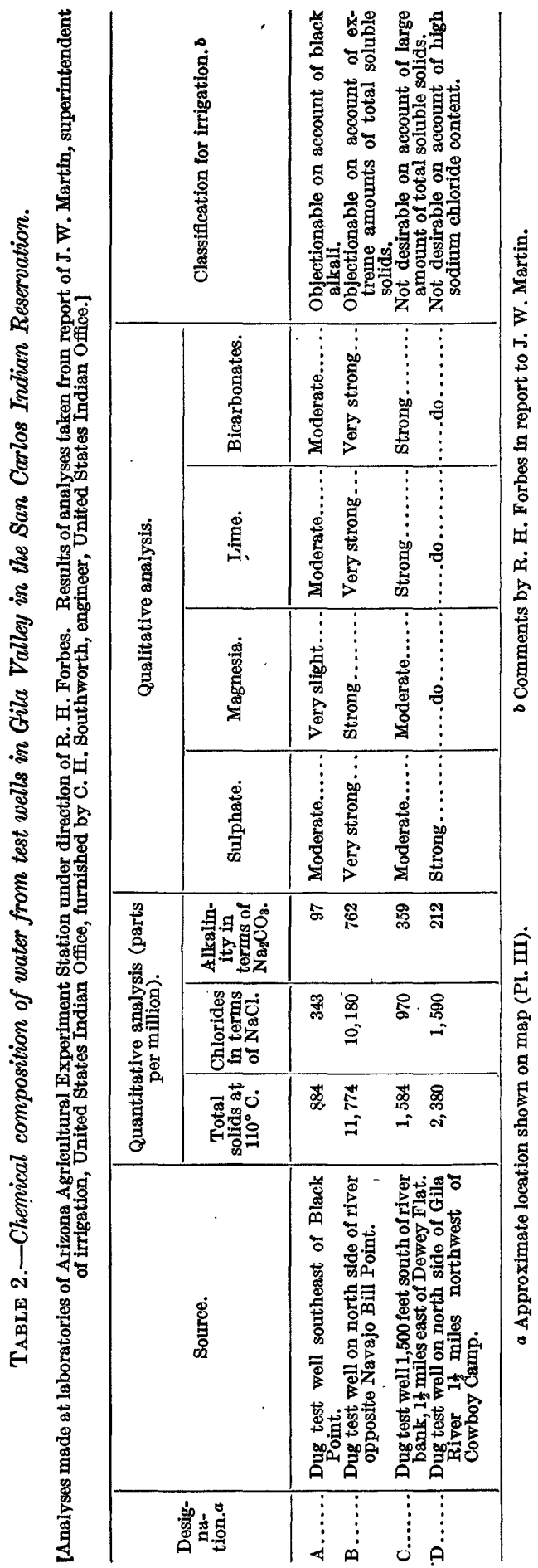




\section{USE FOR IRRIGATION.}

Although no definite tests have been made there is reason to believe that the recent alluvium would yield enough water, if pumped from shallow wells, to irrigate all the arable lands. As the principal contributions to the ground-water supply are received from seepage of the streams into the bottoms and sides of the stream channels, wells should be located as near the channels as possible if large yields are desired. Wells and pumping plants should, however, be placed where there is no danger that they will be washed out, for the streams are continually changing their courses and wearing away the lands adjacent to their channels.

Irrigation with water pumped from wells would have an important advantage over irrigation with surface water in that the supply would be nearly uniform throughout the year, whereas surface supplies are most abundant when irrigation is not needed and least abundant in the dry season. Its cost would be considerably higher than the present cost of irrigating with surface water, but this higher cost would be compensated to a large extent by an increased crop yield made possible by an assured water supply in the dry season, during which the crops often suffer.

The principal objection to the use of water from wells is the poor quality of the water. The waters of the Gila Valley are so heavily impregnated with mineral matter as to require extraordinary precautions to prevent the accumulation of an injurious amount of alkali in the soil, and it is doubtful whether they could be successfully used for any length of time even under the most favorable conditions of soil and drainage. The data as to the quality of the ground waters of the San Carlos Valley are meager, but there is reason to believe that these waters are better than those of the Gila Valley.

Final judgment as to the availability of the shallow ground waters may well be deferred until practical tests have been made and their effects on crops noted under actual working conditions. Experiments of this kind should be carried on at the Bylas farm, in the Gila Valley, where a small pumping plant has lately been installed, and similar experiments should be made in the San Carlos Valley.

To the extent that the shallow ground water is found to be good enough for irrigation, it can be used advantageously on the tracts now under cultivation to supplement the inadequate surface water supply, and also on the arable tracts that lie above the present ditch system.

\section{ARTESTAN WATER.}

The principles upon which artesian flows from sedimentary rocks depend are explained in textbooks on geology and in many of the publications of the United States Geological Survey. The necessary 
conditions are concisely stated by T. C. Chamberlin ${ }^{1}$ as follows: (1) A pervious stratum to permit the entrance and the passage of the water; (2) a water-tight bed below to prevent the downward escape of the water; (3) a like impervious bed above to prevent escape upward, for the water, being under pressure from the fountain head, would otherwise find relief in that direction; (4) an inclination of these beds so that the edge at which the waters enter will be higher than the surface at the well; (5) a suitable exposure of the edge of the pervious stratum, so that it may take in a sufficient supply of water; (6) rainfall adequate to furnish this supply; (7) absence of any means of escape for the water at a lower level than the surface at the well.

In the Gila Basin and in the lower part of the San Carlos Basin the essential conditions for an artesian flow as stated above are believed to be fulfilled, the Gila conglomerate serving as the pervious stratum for the entrance and passage of the water, the rock floor upon which it rests serving as the lower impervious stratum, and the lake beds serving as the upper impervious stratum. (SeesectionD-D ${ }^{1}$, Pl. II.)

Wherever the Gila conglomerate is exposed it has the appearance of a good water-bearing material. Its outcrops along the flanks of the ranges, several hundred feet above the river valleys, provide a large intake area for the absorption of direct rainfall and run-off from the mountains above. If the conglomerate extends to the axes of the basins and is of the same character as at the outcrops, it fulfills the first requisite given 'above. Its character near the axes of the basins, where it is hidden beneath the overlying formations, can only be conjectured. It probably contains less coarse material there than where it crops out, but there is no reason to believe that it is entirely devoid of water-bearing gravels.

The rock basins in which the Gila conglomerate lies appear to be sufficiently tight to prevent the escape of ground water. At their lower ends the Gila and San Carlos basins are closed by mountains that allow the eseape of surface water through a narrow gorge (the box canyon), but are believed to hold back effectively the deep ground waters. The rock floor of the basins is likewise believed to be sufficiently impervious to prevent the escape of ground water downward and out of the basins.

The lake beds occupy the middle parts of the basins and extend far up on the sides, blanketing the Gila conglomerate to elevations several hundred feet above the river valleys. On the whole they seem to be an effective artesian cover, comparatively free from fractures and sufficiently impervious in themselves to prevent, at

1 U. S. Geol. Survey Fifth Ann. Rept., pp. 134-135, 1885. 
least in part, the upward escape of water imprisoned beneath them. Along the north side of the Gila Valley, opposite Navajo Bill Point and at several other places farther east, small springs issue near the base of the bluffs. A group of springs occurs in the large arroyo which enters the Gila from the north opposite Bylas siding. There is another spring in Kelly Wash, on the south side of the basin, 2 miles southeast of San Carlos. (See Pl. II.) If these springs represent leakage from the artesian reservoir, as seems probable, the lake beds are not perfectly water-tight, but apparently the amount of water lost in this way is not great. At a number of places there are also evidences of a possible disturbance of the artesian cover, as indicated by lava intrusions and slight folding and faulting.

In the Gila Básin favorable artesian conditions exist along the north side of the basin for 15 miles from the east boundary of the reservation to a point 8 miles east of the Triplets. Farther west the Gila conglomerate is not exposed and consequently the artesian prospects are not so good. On the south side of the Gila Basin favorable artesian conditions are found for a distance of 20 miles below Bylas and a point 4 miles east of the box canyon.

In the San Carlos Basin artesian structure exists along the west side for 5 miles northward from the box canyon. Beyond that point the structure may be less favorable on account of possible serious disarrangements of the strata as a result of volcanic disturbances, which are indicated by numerous lava flows. On the east side the absence of outcrops of the Gila conglomerate makes conditions unfarorable.

As the structure is favorable to artesian conditions on one or both sides of the Gila Basin between the east boundary of the reservation and San Carlos, there are prospects that artesian water can be obtained in the river valley between these points by drilling through the recent alluvium and lake beds into the Gila conglomerate.

As the structure is favorable to artesian conditions on the west side of the San Carlos Basin for 5 miles north from the box canyon, there are also prospects that artesian water can be obtained in the river valley from San Carlos north to the new San Carlos steel bridge. All this part of the valley, however, is inside the proposed reservoir site. In the part of the San Carlos Valley above the steel bridge conditions do not appear to be favorable for obtaining an artesian supply.

According to the writer's estimates, based entirely on the probable relative positions of the formations as represented graphically in the cross sections in Plate II, the average thickness of the lake beds near the middle parts of the basins does not exceed 700 feet. However, as no complete sections are exposed, this estimate may be much too low. As the lake beds were laid down on an eroded and somewhat 
hilly surface, their thickness probably varies from place to place. In some places it may be necessary to drill 1,000 or even 1,500 feet to reach the Gila conglomerate, and as much as 2,000 feet to penetrate the conglomerate deep enough to make a conclusive test.

It is impossible from data obtained in a geologic investigation to predict definitely the presence or absence of artesian water, for the reason that unfavorable conditions may exist underground which do not appear at the surface. However, the investigation that has been made shows that the conditions, in so far as they can be observed, are sufficiently favorable to warrant the drilling of a test well.

As no wells have been drilled into the Gila conglomerate, the quality of the water which it contains is not known. The source of the water is the rain on the outcrop and the run-off from the hard igneous and sedimentary rocks of the mountains above. The water as it enters the Gila conglomerate is therefore probably only moderately mineralized. In passing downward to lower levels through the conglomerate it dissolves more or less mineral matter, but, to judge from the character of the materials in this formation as revealed in its outcrops, the amount of soluble matter is not large. There may, however, be buried saline beds along the axes of the valleys. In view of the source of the water contained in the Gila conglomerate and the character of the formation, there is reason to believe that the water is good enough for use.

\section{SUMMART AND CONCIUSIONS.}

1. The part of the Gila Valley within the reservation and outside of the proposed reservoir site contains about 4,595 acres of arable land. In 1913 only 421 acres, or less than 10 per cent of this arable land, was irrigated and farmed.

2. The San Carlos Valley, all of which lies within the reservation, contains 1,840 acres of arable land above the proposed reservoir site. In 1913,538 acres, or a little more than 30 per cent, of this arable land was irrigated and farmed.

3. On account of the lack of sufficient water in Gila and San Carlos rivers during a certain period in summer when irrigation is most needed and on account of the difficulty of maintaining diversion dams and canals, the system of irrigation in 1914 was inadequate.

4. In the river valleys water in sufficient quantities for irrigation can probably be obtained by pumping from shallow wells in the alluvium.

5. The principal source of the water in the valley alluvium is believed to be seepage from the rivers. Consequently the largest yields may be expected from wells near the river channels. 
6. In 1913 the cost of irrigating under the present system was $\$ 1.34$ an acre. The cost of pumped well water would probably be higher.

7. The waters from shallow wells in the Gila Valley are heavily mineralized. They are so high in chlorine, which is one of the constituents of common salt, that they are of doubtful value for irrigation, and if used continuously they would require extraordinary precautions to prevent an excessive accumulation of alkali in the soil.

8. The shallow ground waters in the San Carlos Valley are believed to be better than those of the Gila Valley and comparable to the water from Gila River, which is now successfully used for irrigation.

9. Final judgment on the suitability of the shallow ground waters for irrigation should be deferred until their effect on crops has been determined by actual experiment.

10. To the extent that the shallow ground waters are found to be good enough for irrigation they can be advantageously used on the tracts already under cultivation to supplement the surface-water supply and on arable tracts that lie above the ditches.

11. In the Gila Basin structure favorable to artesian conditions exists on one or both sides of the valley between the east boundary of the reservation and San Carlos, and it is believed that artesian water can be obtained in the river valley between these points.

12. In the San Carlos Basin structure favorable to artesian conditions exists only on the west side adjacent to that part of the valley included within the proposed reservoir.

13. To test the water-bearing possibilities of the Gila conglomerate it will be necessary to drill through the Recent alluvium and the lake beds, which, according to the writer's es timates, have an average thickness below the river valleys of not more than 700 feet. In some places it may be necessary to drill 1,000 to 2,000 feet to test the existence of water-bearing beds.

14. The structure appears most favorable on the south side of the Gila Basin, west of Bylas. A good location for a test well would be on Dewey Flat or on the 180-acre tract of arable land 1 mile east of Dewey Flat.

15. There is no direct information as to the quality of the water in the Gila conglomerate, but it is probably good enough to be used for irrigation.

16. Unfavorable conditions may exist underground that will make it impossible to obtain artesian wells, but the conditions as observed at the surface are sufficiently favorable to warrant the drilling of a test well. 